\title{
Pengaruh interaksi antara faktor minat belajar dengan penerapan model pembelajaran drill and practice dan open ended problems terhadap rata-rata hasil belajar teknik animasi 2d dan 3d pada siswa kelas x SMK PGRI 3 Malang
}

\author{
Sheila Ramadani ${ }^{1}$, Setiadi Cahyono Putro ${ }^{2}$, Yuni Rahmawati ${ }^{3}$ \\ 1. Universitas Negeri Malang, Indonesia | danishei-la27@gmail.com \\ 2. Universitas Negeri Malang, Indonesia | setiadi.cahyono.ft@um.ac.id \\ 3. Universitas Negeri Malang, Indonesia | yuni.rahmawati.ft@um.ac.id
}

\begin{abstract}
Abstrak:
Tujuan penelitian ini untuk: (1) mengungkap capaian rata-rata hasil belajar Teknik Animasi 2D dan 3D siswa kelas $X$ Jurusan Multimedia di SMK PGRI 3 Malang, (2) mengungkap pengaruh interaksi antara faktor minat belajar dengan faktor model belajar Drill and Practice dan Open Ended Problems terhadap rata-rata hasil belajar Teknik Animasi 2D dan 3D siswa kelas X Jurusan Multimedia di SMK PGRI 3 Malang, dan (3) mengungkap yang paling berbeda diantara empat kelompok rata-rata hasil belajar Teknik Animasi 2D dan 3D siswa karena faktor minat belajar dengan faktor model belajar Drill and Practice dan Open Ended Problems yang saling diperbandingkan. Hasil an-alisis data yang diperoleh yaitu (1) rata-rata hasil belajar kelompok minat belajar tinggi dengan penerapan model pembelajaran Drill and Practice mendapatkan nilai dengan kriteria tertinggi sebesar $50 \%$, (2) rata-rata hasil belajar kelompok minat belajar tinggi dengan model pembelajaran Open Ended Problems mendapatkan nilai kriteria tertinggi sebesar $60 \%$, (3) rata-rata hasil belajar kelompok minat belajar rendah dengan model pembelajaran Drill and Practice mendapatkan nilai kriteria tertinggi sebesar 40\%, dan (4) rata-rata hasil belajar kelompok minat belajar rendah dengan model pembelajaran Open Ended Problems mendapatkan nilai kriteria tertinggi sebesar $10 \%$.
\end{abstract}

\section{Kata Kunci}

Hasil Belajar, Minat Belajar, Drill and Practice, Open Ended Problems, dan Teknik Animasi 2D dan 3D. 


\section{TEKNO Jurnal Teknologi Elektro dan Kejuruan}

http://journal2.um.ac.id/index.php/tekno | ISSN 1693-8739

\section{Pendahuluan}

Pendidikan merupakan hal yang penting untuk membangun karakter bangsa di Indonesia. Dengan adanya pendidikan, sudah seharusnya sumber daya manusia yang terampil, kreatif, aktif dan inovatif dapat terwujud selaras dengan perkembangan zaman (Arikunto,2006). Terdapat banyak aspek yang dapat menjadi faktor untuk mewujudkan pendidikan yang berkualitas di sekolah salah satunya yaitu proses pembelajaran (Candra,2016).

Berdasarkan hasil observasi dengan pengamatan dan wawancara guru mata pelajaran Teknik Animasi 2D dan 3D dan pengalaman mengajar di SMK PGRI 3 Malang jurusan Multimedia mata pelajaran Teknik Animasi 2D dan 3D pada Kompetensi Dasar Teknik Animasi Tweening, proses pembelajaran yang terjadi adalah sebagai berikut: (1) kebanyakan siswa tidak memiliki rasa tanggung jawab terhadap tugas, siswa cenderung meremehkan perintah untuk mengerjakan tugas praktek (Cuntaka,2014). Misalnya siswa diminta untuk membawa properti sebagai bahan untuk membuat animasi, tetapi siswa yang membawa properti hanya sebagian kecil saja sehingga masalah tersebut akan menghambat berlangsungnya pembelajaran, (2) siswa dengan minat belajar rendah tidak mampu memahami materi, menurut pengamatan yang telah dilakukan dalam diskusi kelompok, siswa dengan minat belajar rendah tidak ikut serta dalam proses pembuatan animasi (Gunawan,2013). Siswa dengan minat belajar rendah cenderung melakukan kegiatan lain seperti tidur, bermain game dan bergurau, (3) siswa dengan minat belajar rendah bergantung pada siswa dengan minat belajar tinggi, siswa dengan minat belajar rendah tidak ikut berpartisipasi dalam mengerjakan, dan (4) hasil belajar siswa rendah (Huda,2013).

Hasil belajar merupakan hasil dari suatu interaksi tindak belajar dan tindak mengajar (Dimyati dan Mudjiono,2006), . Yang dimaksud dengan tindak belajar dan mengajar adalah dari sisi guru, tindak mengajar diakhiri dengan proses evaluasi hasil belajar (Khofiya,2014).

Untuk meningkatkan hasil belajar siswa, perlu diperhatikan karakteristik siswa dan mata pelajaran (Kusumaningrum,2016). Salah satu karakteristik siswa yang perlu diperhatikan adalah minat belajar siswa. Minat adalah gejala psikologis yang menunjukkan pemusatan perhatian terhadap suatu obyek sebab ada perasaan senang (Tidjan,1976). Siswa yang memiliki minat terhadap subjek tertentu cenderung untuk memberikan perhatian yang lebih besar terhadap subjek tersebut (Slameto dalam Sardini,2013),.

Kelebihan yang dimiliki oleh Drill and Practice diantaranya sebagai berikut: Pembentukan kebiasaan yang dilakukan dengan mempergunakan metode ini akan menambah ketepatan dan kecepatan pelaksanaan, (2) pemanfaatan kebiasaan-kebiasaan tidak memerlukan banyak konsentrasi dalam pelaksanaannya, dan (3) pembentukan kebiasaan membuat gerakan-gerakan yang kompleks, rumit menjadi otomatis, habitation makes complex movement more automatic (Sagala,2014).

Ada beberapa asumsi yang mendasari Open Ended Problems antara lain (a) Konteks dan Pengalaman, (b) Mediasi Pem-ahaman, (c) Meningkatkan Proses Kognitif, (d) Pentingnya Pemahaman, (e) Proses Pembelajaran (Miftachul,2013).

TEKNO Vol. 27 Issue 2, p170-179 | Jurusan Teknik Elektro, Universitas Negeri Malang, Indonesia | September 2017

S. Ramadani, S.C. Putro, Y. Rahmawati | Pengaruh interaksi antara faktor minat belajar dengan penerapan... 


\section{TEKNO Jurnal Teknologi Elektro dan Kejuruan}

http://journal2.um.ac.id/index.php/tekno | ISSN 1693-8739

Animasi adalah suatu teknik yang banyak sekali digunakan dalam dunia film dewasa ini, baik sebagai suatu kesatuan yang utuh, bagian dalam suatu film maupun bersatu dalam film life (Syahfitri,2011). Pada jurusan Multimedia di SMK, mata pelajaran Teknik Animasi 2D dan 3D diberikan guna menuntun siswa untuk dapat mengetahui teknik-teknik membuat gambar animasi 2D dan 3D."Dalam kaitannya dengan cerita dan gambar, penulis beranggapan bahwa animasi merupakan kegiatan menghidupkan sebuah cerita dari beberapa gambar yang berkesinambungan sehingga ketika dalam proses animasi gambar tersebut terlihat seperti hidup" (Pamungkas,2011).

Berdasarkan latar belakang tersebut, tujuan penelitian ini adalah untuk: (1) mengungkap capaian rata-rata hasil belajar Teknik Animasi 2D dan 3D siswa kelas $X$ Jurusan Multimedia di SMK PGRI 3 Malang, (2) mengungkap pengaruh interaksi antara faktor minat belajar dengan faktor model belajar Drill and Practice dan Open Ended Problems terhadap rata-rata hasil belajar Teknik Animasi 2D dan 3D siswa kelas X Jurusan Multimedia di SMK PGRI 3 Malang, dan (3) mengungkap yang paling berbeda diantara empat kelompok rata-rata hasil belajar Teknik Animasi 2D dan 3D siswa karena faktor minat belajar dengan faktor model belajar Drill and Practice dan Open Ended Problems yang saling diperbanding-kan (Majid,2013) (Widodo, 2013).

\section{Metode}

Penelitian ini merupakan penelitian jenis true experiment dengan menggunakan rancangan penelitian faktorial $2 \times 2$ yang bertujuan untuk mengetahui perbandingan keefektifan suatu model pembelajaran yaitu Drill and Practice dan Open Ended Problems yang dilaksanakan pada siswa dengan tingkat minat belajar tinggi (MT) dan minat belajat rendah (MR) terhadap rata-rata hasil belajar keterampilan mata pelajaran Teknik Animasi 2D dan 3D di SMK PGRI 3 Malang (Maulina,2011). Dalam penelitian ini menggunakan dua variabel bebas yaitu minat belajar siswa dan model pembelajaran yang terdiri dari Drill and Practice (A) dan model pembelajaran Open Ended Problems (B).

Dalam penelitian ini terdapat empat sampel yang masing-masing menggunakan model pembelajaran Drill and Practice dan Open Ended Problems yaitu: (1) kelompok siswa yang memiliki minat belajar tinggi dengan model pem-belajaran Drill and Practice, (2) kelompok siswa yang memiliki minat belajar tinggi dengan model pembelajaran Open Ended Problems, (3) kelompok siswa yang memiliki minat belajar rendah dengan model pembelajaran Drill and Practice, dan (4) kelompok siswa yang memiliki minat belajar rendah dengan model pembelajaran Open Ended problems (Murni,2016).

Subjek dari penelitian ini adalah siswa kelas X (sepuluh) tahun ajaran 2016/2017 SMK PGRI 3 Malang jurusan Multimedia (Nazir,2005). Untuk kelas yang digunakan sebagai kelas eksperimen adalah kelas X Multimedia B dan X Multimedia C karena kedua kelas memiliki alokasi waktu pembelajaran yang sama. Pada penelitian ini kelas Multimedia B dan Multimedia $\mathrm{C}$ akan dibagi menjadi empat kelas eksperimen berdasarkan dari hasil pengisian angket minat belajar (Nurhayati,2013).

TEKNO Vol. 27 Issue 2, p170-179 | Jurusan Teknik Elektro, Universitas Negeri Malang, Indonesia | September 2017

S. Ramadani, S.C. Putro, Y. Rahmawati | Pengaruh interaksi antara faktor minat belajar dengan penerapan... 


\section{TEKNO Jurnal Teknologi Elektro dan Kejuruan}

http://journal2.um.ac.id/index.php/tekno | ISSN 1693-8739

Instrumen perlakuan pada penelitian ini berupa model pembelajaran Drill and Practice dan Open Ended Problems. Instrumen pembelajaran pada penelitian ini berupa silabus, Rencana Pelaksanaan Pembelajaran (RPP), Jobsheet, dan kisi-kisi soal keterampilan. Sedangkan instrumen yang digunakan dalam penelitian ini berkaitan dengan pengukuran minat belajar dan hasil belajar ranah keterampilan siswa (Pamungkas,2012).

Untuk mendapatkan taraf minat belajar siswa dapat dilihat dari skor angket yang disebarkan. Semakin rendah skor yang didapatkan menunjukkan minat belajar yang tinggi, sebaliknya jika skor yang didapatkan tinggi maka akan menunjukkan minat belajar rendah. Indikator angket minat belajar yaitu (1) perasaan senang, (2) ketertarikan siswa, (3) Perhatian siswa, dan (4) keterlibatan siswa. Untuk minat siswa memiliki dua kategori yaitu minat tinggi dan minat rendah. Sedangkan hasil belajar ranah keterampilan dikategorikan men-jadi 5 kategori yaitu (1) sangat tinggi, (2) tinggi, (3) sedang, (4) rendah, dan (5) sangat rendah (Safari 2003).

Analisis data dalam penelitian ini bertujuan untuk: (1) mengetahui signif-ikansi perbedaan tingkat minat belajar antara keempat kelompok, (2) interaksi an-tara faktor minat belajar dengan variasi model pembelajaran terhadap hasil belajar ranah keterampilan, (3) ratarata hasil yang berbeda antara ke-empat kelompok hasil belajar (Putro,2014).

Uji hipotesis yang diuji untuk perbedaan hasil belajar antara faktor minat rendah dan faktor minat tinggi yang dibelajarkan menggunakan model pembelaja-ran Drill and Practice dan Open Ended Problems adalah apakah terdapat perbe-daan hasil belajar ranah keterampilan teknik animasi 2D dan 3D antara tingkat minat belajar siswa dengan varian model pembelajaran (Rahayu,2015).

Uji hipotesis yang diuji untuk interaksi antara faktor minat rendah dan faktor minat tinggi yang dibelajarkan menggunakan model pembelajaran Drill and Practice dan Open Ended Problems adalah apakah terdapat interaksi antara ting-kat minat belajar siswa dengan varian model pembelajaran terhadap rata-rata hasil belajar ranah keterampilan teknik animasi 2D dan 3D (Roestiyah,2008).

\section{Hasil}

Tabel 1 menunjukkan jumlah frekuensi masing-masing kelompok belajar (Roida,2010). Dapat dilihat bahwa kelompok siswa dengan minat belajar rendah yang dibelajarkan menggunakan model pembelajaran Drill and Practice mendapatkan frekuensi pada kriteria sangat tinggi sebesar 8 , tinggi 8 , dan sedang 5. Sedangkan untuk ke-lompok siswa minat tinggi yang dibelajarkan menggunakan model pembelajaran Drill and Practice mendapatkan frekuensi pada kriteria sangat tinggi sebesar 8 , tinggi 6 , sedang 2 . Untuk kelompok siswa minat rendah yang dibelajarkan menggunakan model pembelajaran Open Ended Problems mendapatkan frekuensi pada kriteria sangat tinggi sebesar 2, tinggi 8, sedang 8 dan rendah 3. Dan untuk kelompok kelas minat tinggi yang dibelajarkan menggunakan model pembelajaran Open Ended Problems mendapatkan frekuensi pada kriteria paling tinggi 9, tinggi 5 dan sedang 1.

TEKNO Vol. 27 Issue 2, p170-179 | Jurusan Teknik Elektro, Universitas Negeri Malang, Indonesia | September 2017

S. Ramadani, S.C. Putro, Y. Rahmawati | Pengaruh interaksi antara faktor minat belajar dengan penerapan... 


\section{TEKNO Jumal Teknologi Ekekrio dan Kejurvon}

http://journal2.um.ac.id/index.php/tekno | ISSN 1693-8739

Tabel 1. Jumlah frekuensi masing-masing kelompok belajar

\begin{tabular}{cccccc}
\hline \multirow{2}{*}{ No } & \multirow{2}{*}{ Kriteria } & \multicolumn{4}{c}{ Jumlah Frekuensi } \\
\cline { 3 - 6 } & & MRA & MTA & MRB & MTB \\
\hline 1 & Sangat Tinggi (ST) & 8 & 8 & 2 & 9 \\
2 & Tinggi (T) & 8 & 6 & 8 & 5 \\
3 & Sedang (S) & 5 & 2 & 8 & 1 \\
4 & Redah (R) & 0 & 0 & 3 & 0 \\
5 & Sangat Rendah (SR) & 0 & 0 & 0 & 0 \\
\hline
\end{tabular}

Tabel 2 menunjukkan frekuensi masing-masing kelompok belajar yang dapat diketahui bahwa kelompok siswa minat tinggi yang dibelajarkan menggunakan model pembelajaran Open Ended Problems memiliki presentasi interval hasil bela-jar sangat tinggi dengan persentasi paling besar yaitu 60\%, sedangkan kelompok siswa minat rendah yang dibelajarkan menggunakan model pembelajaran Open Ended Problems memiliki presentasi interval hasil belajar sangat tinggi dengan persentasi paling kecil yaitu $10 \%$.

Tabel 2. Interval Hasil Belajar Ranah Keterampilan

\begin{tabular}{lllll}
\hline Kriteria & $\begin{array}{l}\text { f } \% \\
\text { MRA }\end{array}$ & $\begin{array}{l}\text { f } \\
\text { MTA }\end{array}$ & $\begin{array}{l}\text { f } \% \\
\text { MRB }\end{array}$ & $\begin{array}{l}\text { f } \% \\
\text { MTB }\end{array}$ \\
\hline Sangat & $40 \%$ & $50 \%$ & $10 \%$ & $60 \%$ \\
Tinggi (ST) & & & & \\
Tinggi (T) & $40 \%$ & $38 \%$ & $40 \%$ & $33 \%$ \\
Sedang (S) & $20 \%$ & $12 \%$ & $40 \%$ & $6 \%$ \\
Redah (R) & $0 \%$ & $0 \%$ & $14 \%$ & $0 \%$ \\
Sangat & $0 \%$ & $0 \%$ & $0 \%$ & $0 \%$ \\
Rendah & & & & \\
(SR) & & & & \\
\hline
\end{tabular}

Tabel 3 menunjukkan data hasil belajar ranah keterampilan siswa. dapat diketahui bahwa rata-rata hasil belajar ranah keterampilan setelah diberi perlakuan yang tertinggi terdapat pada kelas dengan tingkat minat tinggi yang diberikan perlakuan dengan menggunakan model pembelajaran Open Ended Problems. Sedangkan ra-ta-rata hasil belajar setelah diberi perlakuan yang terendah terdapat pada kelas dengan tingkat minat rendah yang diberi perlakuan dengan menggunakan model pembelajaran Open Ended Problems (Rusman,2014).

Tabel 3. Hasil Belajar Ranah Keterampilan

\begin{tabular}{llll}
\hline Kelas & Nilai Terendah & Nilai Tertinggi & Nilai Rata-rata \\
\hline MRA & 45 & 90 & 69,76 \\
MTA & 55 & 95 & 74,69 \\
MRB & 40 & 80 & 57,62 \\
MTB & 55 & 95 & 77,67 \\
\hline
\end{tabular}

Tabel 4 merupakan deskripsi data hasil uji hipotesis interaksi minat dan var-ian model pembelajaran. Dapat dikatakan bahwa tiap model pembelajaran mem-iliki rata-rata hasil belajar 


\section{TEKNO Jurnal Teknologi Elektro dan Kejuruan}

http://journal2.um.ac.id/index.php/tekno | ISSN 1693-8739

yang sama. Minat berlajar memiliki $F$ hitung 16,360 dengan nilai signifikansi 0,000 kurang dari 0,05 maka dapat dikatakan bahwa tingkatan minat belajar memiliki rata-rata hasil belajar yang berbeda. Sedangkan Model * Minat memiliki F hitung sebesar 5,999 dengan signifikansi sebesar 0,017 kurang dari 0,05 maka dapat dikatakan bahwa $\mathrm{H} 0$ ditolak yang artinya rata-rata hasil belajar siswa untuk interaksi antara model pembelajaran dan minat belajar adalah berbeda.

Tabel 4. Hasil Uji Hipotesis Interaksi Minat dan Varian Model Pembelajaran

\begin{tabular}{llll}
\hline Source & Mean & F & Sig. \\
\hline Model & 374,204 & 2,203 & 0,142 \\
Minat & 2779,181 & 16,360 & 0,000 \\
Model * Minat & 1019,032 & 5,999 & 0,017 \\
\hline
\end{tabular}

Tabel 5 merupakan hasil uji hipotesis perbedaan hasil belajar. Dapat diketahui bahwa nilai hitung $F$ sebesar 8,587 dengan signifikansi 0,000 kurang dari 0,005 sehingga dapat dikatakan bahwa $\mathrm{HO}$ ditolak yang artinya terdapat perbedaan rata-rata hasil belajar teknik animasi 2D dan 3D yang signifikan antara kelas dengan tingkat minat tinggi dan minat rendah yang dibelajarkan menggunakan model pembelajaran Drill and Practice dan kelas dengan tingkat minat tinggi dan minat rendah yang dibelajarkan menggunakan model pembelaja-ran Open Ended Problems (Safari,2003).

Tabel 5. Hasil Uji Hipotesis Perbedaan Hasil Belajar

\begin{tabular}{lllll}
\hline & $\begin{array}{l}\text { Sum of } \\
\text { Squares }\end{array}$ & Mean & F & Sig. \\
\hline $\begin{array}{l}\text { Between } \\
\text { Groups }\end{array}$ & 4376,412 & 1458,804 & 8,587 & 0,000 \\
Within & 11721,533 & 169,877 & & \\
Group & & & & \\
Total & 16097,945 & & & \\
\hline
\end{tabular}

Selanjutnya hasil dari uji hipotesis Post Hoc rata-rata hasil belajar ranah keterampilan terlihat pada Tabel 6 . Terdapat 3 dari 6 pasang data memiliki perbedaan signifikan. Drill and Practice dengan minat belajar rendah dan Open Ended Problems dengan minat belajar rendah memiliki perbedaan nilai yang paling signifikan yaitu 12.143 dengan nilai signifikansi 0,035. Selanjutnya Drill and Practice dengan minat belajar tinggi dan Open Ended Problems dengan minat belajar rendah memiliki perbedaan nilai sebesar 17,068 dengan nilai signifikansi 0,003. Open Ended Problems dengan minat belajar tinggi dan Open Ended Problems dengan minat belajar rendah memiliki perbedaan nilai sebesar 20,048 dengan nilai signifikansi 0,000. Sedangkan Drill and Practice dengan minat belajar tinggi dan Drill and Practice dengan minat belajar rendah, Open Ended Problems dengan minat belajar tinggi dan Drill and Practice dengan minat belajar rendah serta Open Ended Problems dengan minat belajar tinggi dan Drill and Practice dengan minat belajar tinggi tidak terdapat perbedaan yang signifikan. 


\section{TEKNO Jurnal Teknologi Elektro dan Kejuruan}

http://journal2.um.ac.id/index.php/tekno | ISSN 1693-8739

Tabel 6. Uji Hipotesis Post-Hoc Rata-rata Hasil Belajar Ranah keterampilan

\begin{tabular}{lllll}
\hline (I) Minat & (J) Minat & Mean Difference (I-J) & Std. Error & Sig. \\
\hline MRA & MRB & $12.143^{*}$ & 4,022 & 0,035 \\
MTA & MRB & $17,068^{*}$ & 4.325 & 0,003 \\
MTB & MRB & $20,048^{*}$ & 4,406 & 0,000 \\
\hline
\end{tabular}

Jadi, dapat disimpulkan bah-wa kelompok minat belajar tinggi dengan model pembelajaran Open Ended Problems mendapatkan persentase terbesar pada kriteria nilai sangat tinggi yaitu sebesar $60 \%$ dan kelompok minat belajar rendah dengan model pembelajaran Open Ended Problems mendapatkan persentase terkecil pada kriteria nilai sangat tinggi yaitu sebesar $10 \%$.

Pendekatan open ended menjanjikan suatu kesempatan kepada siswa untuk menginvestigasi berbagai strategi dan cara yang diyakini sesuai dengan kemampuan menelaborasi permasalahan (Shoimin,2013) menjelaskan bahwa. Dari pendapat tersebut menunjukkan bahwa model pembelajaran Open Ended Problems dapat memberikan kesempatan kepada siswa untuk menyelesaikan permasalahan dengan cara mereka sendiri, sehingga siswa dengan tingkat minat belajar rendah tidak mampu untuk menyelesaikan tugas sedangkan siswa dengan tingkat minat belajar tinggi akan merasa tertantang dan lebih bersemangat dalam menyelesaikan tugas.

Hasil uji hipotesis menggunakan ANOVA dua jalur dengan metode test of betweensubject effect menunjukkan bahwa tingkat minat belajar siswa yang dikolaborasikan dengan model belajar Drill and Practice dan Open Ended Problems memiliki pengaruh yang signifikan terhadap rata-rata hasil pembelajaran Teknik Animasi 2D dan 3D. Hal tersebut ditunjukkan dengan probabilitas perbedaan yang diperoleh masih di bawah taraf signifikan, sehingga $\mathrm{HO}$ ditolak yang membuktikan bahwa terdapat interaksi antara tingkat minat belajar siswa dengan varian model pembelajaran. Interaksi antara minat belajar siswa dan varian model pembelajaran terhadap rata-rata hasil belajar teknik animasi 2D dan $3 \mathrm{D}$

Berdasarkan hasil uji hipotesis menggunakan ANOVA dua jalur menun-jukkan bahwa terdapat perbedaan hasil belajar yang signifikan antara siswa dengan tingkat minat belajar tinggi dan siswa dengan tingkat minat belajar rendah yang dibelajarkan menggunakan model pembelajaran Drill and Practice dan model pembelajaran Open Ended Problems. Hal ini terlihat dari perbedaan rata-rata hasil belajar siswa aspek keterampilan dengan tingkat minat belajar tinggi dan siswa dengan tingkat minat belajar rendah yang dibelajarkan menggunakan model pem-belajaran Drill and Practice dan Open Ended Problems yang memiliki probabilitas perbedaan yang jauh di bawah taraf signifikansi.

Adanya perbedaan tersebut dimungkinkan karena perbedaan karakteristik tiap individu. Setiap anak memiliki kemampuan dasar bawaan dan akan mengalami perubahan karena pengalaman, maka dari itu karena kebutuhan anak dan kemampuan dasar bawaannya berbeda maka minat anak dalam belajar akan berbeda (Suryosubroto dalam Robi'ah,2014).

TEKNO Vol. 27 Issue 2, p170-179 | Jurusan Teknik Elektro, Universitas Negeri Malang, Indonesia | September 2017 S. Ramadani, S.C. Putro, Y. Rahmawati | Pengaruh interaksi antara faktor minat belajar dengan penerapan... 


\section{TEKNO Jurnal Teknologi Elektro dan Kejuruan}

http://journal2.um.ac.id/index.php/tekno | ISSN 1693-8739

Sedangkan Berdasarkan hasil uji hipotesis menggunakan post hoc comparisons menunjukkan bahwa terdapat perbandingan rata-rata hasil belajar aspek keterampilan yang memiliki perbedaan paling signifikan diantara rata-rata hasil belajar pada kelas lain. Hal ini terlihat dari nilai mean difference dan nilai signifikan yang jauh dibawah taraf signifikansi. Ratarata hasil belajar antara kelas Drill and Practice dengan minat belajar rendah dan Open Ended Problems dengan minat belajar rendah menunjukkan perbedaan yang paling signifikan jika dibandingkan dengan kelas-kelas lain.

\section{Kesimpulan}

Kesimpulan dari penelitian ini adalah terdapat interaksi antara tingkat min-at belajar siswa dengan model pembelajaran Drill and Practice dan Open Ended Problems terhadap hasil belajar aspek keterampilan pada mata pelajaran Teknik Animasi 2D dan 3D. Hal ini dibuktikan dengan probabilitas perbedaan yang di-peroleh masih di bawah taraf signifikansi.

Serta terdapat perbedaan rata-rata hasil belajar aspek keterampilan yang signifikan antara siswa dengan tingkat minat belajar tinggi dan siswa dengan tingkat minat belajar rendah yang dibelajarkan menggunakan model pembelajaran Drill and Practice dan Open Ended Problems. Hal ini ditunjukkan dengan probabilitas perbedaan rata-rata hasil belajar aspek keterampilan yang masih di bawah taraf signifikansi

Saran yang diajurkan adalah perlu penelitian lebih lanjut mengenai faktor psikologis selain minat yang dapat mempengaruhi hasil belajar siswa. Serta pengaruh model pembelajaran lain yang sesuai dengan psikologis siswa, materi pembelajaran dan sarana prasarana yang tersedia. Perlu dilakukan penelitian dengan tingkat minat yang lebih halus, misalnya minat tinggi, minat sedang, dan minat rendah untuk hasil belajar aspek keterampilan

\section{Daftar Rujukan}

Arikunto, S. 2006. Prosedur Penelitian Suatu Pendekatan Praktik. Jakarta: Rineka Cipta.

Candra, Basukisna. Tanpa Tahun. Penerapan Model Pembelajaran Drill and Practice terhadap Hasil Belajar Chest Pass pada Permainan Bola Basket. Skripsi diterbitkan: (ejournal.unesa.ac.id/article/11003/68/article.pdf). diakses tangal 20 Oktober 2016

Cuntaka, W. 2014. Pengaruh Minat Belajar dan Penerapan Model Pembelajaran Experimental Learning dan Problem Based Learning Terhadap Kompetensi Pemrograman Dasar Pada Siswa Kelas X. Skripsi tidak diterbitkan. FT. Malang.

Dimyati. Mujiono. 2006. Belajar dan Pembelajaran. Jakarta:Rineka Cipta

Gunawan, Iman. 2013. Metode Penelitiaan Kualitatif:Teori dan Pratilik. Jakarta: Bumi Aksara Huda, Miftachul. 2013. Model-model Pengajaran dan Pembelajaran. Malang: Pustaka Pelajar Offset 


\section{TEKNO Jurnal Teknologi Elektro dan Kejuruan}

http://journal2.um.ac.id/index.php/tekno | ISSN 1693-8739

Khofiya, F. 2014. Penerapan Model Pembelajaran Open-Ended Problem dalam Meningkatkan Aktifitas dan Hasil Belajar Siswa Program Keahlian RPL Di SMK Nasional Malang. Skripsi tidak diterbitkan. FT. Malang

Kusumaningrum, P. 2016. Pengaruh Model Pembelajaran Drill and Practice terhadap Hasil Belajar Aspek Pengetahuan dan Retensi Siswa Kelas X Program Keahlian Teknik Komputer dan Jaringan SMKN 11 Malang pada Mata Pelajaran Pemrograman Dasar. Skripsi tidak diterbitkan. FT. Malang.

Majid, Abdul. 2013. Strategi Pembelajaran .Remaja Rosdakarya:Bandung.

Maulina,A. 2011. Pembelajaran Desain Grafis pada Mata Pelajaran Multimedia di SMK Negeri 02 Adiwerna Tegal. Skripsi diterbitkan: (lib.unnes.ac.id/10719/1/122/12.pdf). diakses tanggal 25 Oktober 2016

Murni. 2013. Open-Ended Approach in Learning to Improve Students ThinkingSkills in Banda Aceh. International Journal of Independent Research and Studies ,95-101. (online) dalam (https://publikasiilmiah.ums.ac.id/bitstream/...68_115_Makalah\%20Rev_anita.pdf) diakses tanggal 20 Maret 2017

Nazir, M. 2005. Metode Penelitian. Bogor:Ghalia Indonesia

Nurhayati, Fitri. dkk. 2013. Efektifitas Pembelajaran dengan Metode Drill and Practice dan Learning Cycle 5E disertai Media Pembelajaran Crossword Puzzle terhadap Prestasi Belajar Siswa pada Materi Pokok Hidrokarbon Kelas X Semester Genap SMA Negeri Kebakkramat Tahun pelajaran 2012/2013. Jurnal Pendidikan Kimia (JPK), Vol.2 No. 3, ISSN: 2337-9995, hlm 192-198. (online), dalam (jurnal.fkip.uns.ac.id/index.php/kimia/article/download/2730/1896) diakses 11 November 2016

Pamungkas, Sri. 2012. Bahasa Indonesia dan Berbagai Perspektif. Yogyakarta: Andi.

Putro, Setiadi. 2014. Pengintegrasian Social Cognitive pada Kurikulum S1 Pendidikan Teknik Elektro LPTK untuk Memfasilitasi Kemampuan Beradaptasi Calon Guru Kejuruan. Prosiding Konvensi Nasional Asosiasi Pendidikan Teknologi dan Kejuruan (APTEKINDO) ke 7 FPTK Universitas Pendidikan Indonesia, Bandung, ISBN: 978-602-72004-0-1, hlm 1001-1018. (online), dalam (http://jurnal.upi.edu/3123/author/setiadi-cahyono-putro) diakses 21 Juni 2017

Rahayu, P. 2015. Perbedaan Model Pembelajaran Discovery Learning dan Problem Base Learning berbantuan Handout Berbasis CTL Terhadap Pengetahuan Pemrograman Dasar C++ di SMKN 4 Malang. Skripsi tidak diterbitkan. FT. Malang

Roestiyah. 2008. Strategi Belajar Mengajar. Jakarta:Rineka Cipta

Roida, E. 2010. Pengaruh Minat dan Kebiasaan Belajar Siswa terhadap Prestasi Belajar Matematika. Jurnal Formatif 2 (2), ISSN:2088-351X, hlm.122-131, (online), dalam (http://journal.lppmunindra.ac.id/Roida-3.pdf), diakses 2 November 2016 pukul 9.45 WIB

Rusman. 2014. Model-model Pembelajaran, Mengembangkan Profesionalisme Guru. Jakarta: PT Raja Grafindo Persada 


\section{TEKNO Jurnal Teknologi Elektro dan Kejuruan}

http://journal2.um.ac.id/index.php/tekno | ISSN 1693-8739

Safari, A. 2003. Kurikulum Berbasis Kompetensi. Jakarta: Rineka Cipta

Sagala,S. 2009. Konsep dan Makna Pembelajaran untuk Membantu Memecahkan Problematika Belajar dan Mengajar. Bandung: Alfabeta

Sardini. 2013. Pengaruh Minat Belajar terhadap Hasil Belajar Ekonomi Siswa Kelas XI IPS MAN Pontianak. Skripsi diterbitkan: (juranal.untan.ac.id/index.php/jpdpb/article/view/2777), diakses tanggal 20 Oktober 2016

Sharon, Smaldino, Lowther, Deborah, Russel, James. 2005. Instructional Technology and Media for Learning. NJ: Pearson Education Inc.

Shoimin, Aris. 2014. 68 Model Pembelajaran Inovatif dalam Kurikulum 2103. Yogyakarta: ARRUZZ MEDIA.

Slameto.2010. Belajar \& Faktor-faktor yang mempengaruhi. Jakarta: Rineka Cipta.

Sudarto, 1997, Metode Penelitian Filsafat, Jakarta: Raja Grafindo Persada.

Sudijono, Anas. 2011. Pengantar Evaluasi Pendidikan. Jakarta: Rajawali Pers

Sudjana, Nana. 2011. Penilaian Hasil Proses Belajar Mengajar. Bandung: Rosdakarya Offset.

Suharto, dkk. 2004. Perekayasaan Metodologi Penelitian. Badung:ANDI Yogyakarta

Supardi, dkk. Tanpa Tahun. Pengaruh Media Pembelajaran dan Minat Belajar Terhadap hasil

Belajar Fisika. Jurnal Formatif 2(1), ISSN: 2088-351X, hlm 71-81, (online), dalam

(http://portal.kopertis3.or.id/738Supardi.pdf), diakses tanggal 20 Oktober 2016

Suyono. Hariyanto. 2011. Belajar dan Pembelajaran. Bandung:PT. Remaja Rosdakarya

Syahfitri, Y. 2011. Teknik Film Animasi Dalam Dunia Komputer. Medan: Stmik Trigunadharma

Tidjan. 2001. Evaluasi Pendidikan. Jakarta: Radja Grafindo Persada

Widodo. 2013. Peningkatan Aktivitas Belajar dan Hasil Belajar Siswa dengan Metode Problem

Based Learning VII A. Jurnal Fisika Indonesia No: 49, Vil XVII, ISSN: 1410-2994, hIm 32-35.

(online), dalam (pdm-mipa.ugm.ac.id/ojs/index.php/ji/article/download/831/910), diakses 25

Oktober 2016 